\title{
PERENCANAAN PEMBELAJARAN BAHASA ARAB DI PERGURUAN TINGGI PARIWISATA
}

\author{
Euis Ernawati \\ Sekolah Tinggi Agama Islam Syeikh Mansyur Banten, Indonesia \\ arrayyann@gmail.com
}

\begin{abstract}
This study aims to analyze the lesson plans of Arabic teaching-learning in STIE Pariwisata YAPARI. The researcher hopes that this research can describe the Arabic teachinglearning concept in tourism College. The research uses qualitative approach with descriptive analysis. The research subjects were an Arabic lecturer, and 11 students on their fourth semester. The data were collected by interview and document analysis as triangulation. The result showed that the planning of Arabic teaching-learning can be categorized as good. The vision-mission of institution, curriculum, lesson plan, and academic management were connected well. There were some problems: The campus had no written guideline of lesson plans writing and less of credit semester system. The recommendations of this research were: the campus should make guideline of lesson plans writing and the addition of the number of credit semester system.
\end{abstract}

Keywords: $\quad$ lesson plans, Arabic language, tourism college

\begin{abstract}
Abstrak
Penelitian ini bertujuan untuk menganalisis perencanaan pembelajaran bahasa arab di STIE Pariwisata YAPARI. Adanya penelitian ini diharapkan dapat menggambarkan konsep perencanaan pembelajaran bahasa Arab di perguruan tinggi pariwisata. Penelitian ini menggunakan metode deskriptif dengan pendekatan kualitatif. Subjek penelitian adalah dosen pengajar mata kuliah bahasa Arab dan mahasiswa semester empat jurusan Usaha Perjalanan Wisata STIE Pariwisata YAPARI. Pengumpulan data berupa wawancara, dan analisis dokumen sebagai triangulasi data. Hasil penelitian menunjukan bahwa perencanaan pembelajaran bahasa Arab di sana bisa dikatakan berjalan dengan baik. Ada sinergi yang baik antara visi misi lembaga, kurikulum, rencana pembelajaran semester (RPS), dan manajemen akademik. Kendala yang ditemukan yaitu: belum ada pedoman wajib secara tertulis terkait pembuatan RPS dan kurangnya jumlah sks. Rekomendasi penelitian ini yaitu: hendaknya pihak kampus memberian pedoman wajib pembuatan RPS secara tertulis serta menambahkan jumlah sks.
\end{abstract}

Kata Kunci: perencanaan pembelajaran, bahasa Arab, perguruan tinggi pariwisata 
Arabiyât Jurnal Pendidikan Bahasa Arab dan Kebahasaaraban, 5 (1), 2018

\section{Pendahuluan}

Dalam konteks pengajaran, perencanaan dapat diartikan sebagai serangkaian proses untuk menyusun bahan ajar, media, metode, pendekatan, dan penilaian dalam durasi waktu tertentu untuk mencapai suatu target. ${ }^{1}$ Ketika seorang pendidik mengabaikan hal tersebut, maka kegiatan pembelajaan akan menjadi kurang terarah dan pada akhirnya dapat mengakibatkan kegiatan pembelajaran menjadi kurang optimal. Mata kuliah bahasa Arab merupakan sesuatu hal yang baru di program studi Usaha Perjalanan Wisata. agar kegiatan pembelajaran berjalan dengan lancar, maka perencanaan pembelajaran mutlak diperlukan. Nadzir mengungkapkan bahwa perencanaan memiliki peranan yang amat penting bagi seorang pendidik, khususnya ketika ia menjalankan tugasnya. Suatu kegiatan pembelajaran akan menjadi lebih optimal manakala seorang pendidik terlebih dahulu menyiapkan perencanaan pembelajaran. Selain itu, seorang pendidik juga diharapkan dapat menjadi lebih kreatif dan inovatif dalam merepresentasikan perencanaan pembelajaran yang telah dibuat ke dalam kegiatan belajar yang sebenarnya. ${ }^{2}$ Pendidik dituntut untuk menciptakan suasana belajar yang efektif, inovatif, dan menyenangkan. ${ }^{3}$

Berdasarkan hal tersebut, perencanaan pembelajaran menjadi amat penting untuk dilakukan agar komponen-komponen pembelajaran dapat terorganisir dengan baik. Adapun fenomena yang dikupas dalam penelitian ini meliputi kelengkapan perangkat perencanaan pembelajaran, komponen perencanaan pembelajaran, visi misi lembaga, kurikulum, rencana pembelajaran semester (RPS), dan manajemen akademik.

Agar pelaksanaan pembelajaran berjalan dengan baik, hendaknya sejak awal semester guru sudah harus mempersiapkan perencanaan pembelajaran. Sebagaimana diungkapkan oleh Thomas bahwa seorang pendidik diwajibkan membuat Program Tahunan (Prota), Program Semester (Promes), Silabus dan RPP yang dibuat pada awal tahun dan awal semester dengan mengacu pada Standar Kompetensi dan Kompetensi Dasar (SKKD). ${ }^{4}$

Dalam kegiatan pembelajaran pada umumnya tidak terlepas dari berbagai permasalahan. Adapun permasalahan yang seringkali terjadi dalam pembelajaran bahasa Arab bisa berasal dari berbagai faktor, diantaranya faktor siswa, faktor guru, faktor media yang kurang tepat, dan faktor lainnnya. Hal tersebut sebagaimana yang diungkapkan oleh Khasairi bahwa pembelajaran bahasa Arab seringkali menghadapi berbagai kendala yang mengakibatkan hasil belajar yang dicapai tidak maksimal. Kendala tersebut terkadang berasal dari faktor guru yang kurang professional, kemampuan awal siswa yang rendah, media pembelajaran yang kurang tepat, materi

1 Abdul Majid. Perencanaan Pembelajaran: Mengembangkan Standar Kompetensi Guru, (Bandung: Remaja Rosdakarya, 2011),17.

${ }^{2}$ M. Nadzir. "Perencanaan pembelajaran berbasis karakter". Jurnal Pendidikan Agama Islam. Vol. 02, No. 02, 2013, 339.

${ }^{3}$ Lovy Herayanti, et al. "Pengembangan media pembelajaran berbasis moodle pada matakuliah fisika dasar". Jurnal Cakrawala Pendidikan. 2017, 211.

${ }^{4}$ Partono Thomas. "Manajemen Pembelajaran di SMK Negeri 2 Semarang". Jurnal Pendidikan Ekonomi Dinamika Pendidikan. 2011, 20. 
pelajaran yang kurang memadai, lingkungan yang kurang mendukung, serta evaluasi yang tidak tepat sasaran. Kendala-kendala tersebut merupakan tantangan yang dihadapi pendidik yang berkecimpung dalam bidang bahasa Arab. Dengan keterbatasan yang dimilikinya, pendidik diharapkan dapat melaksanakan tujuan pendidikan secara optimal. ${ }^{5}$

\section{Metode Penelitian}

Penelitian ini menggunakan pendekatan kualitatif. Pendekatan kualitatif dipilih karena lebih relevan dengan fenomena yang diteliti yakni tentang "Perencanaan Pembelajaran Bahasa Arab di Perguruan Tinggi Pariwisata". Pada pendekatan kualitatif ini, penelitian dilakukan pada situasi yang alami. Peneliti menggambarkan fenomena yang terjadi, meneliti kata-kata, dan mengamati perilaku.

Data dalam penelitian ini diperoleh melalui wawancara dan analisis dokumen. Hal tersebut digunakan karena peneliti ingin menggali data secara mendalam dan memahami permasalahan yang ada secara menyeluruh. Dalam paradigma penelitian kualitatif, sudut pandang bersifat holistik (menyeluruh dan tidak dapat dipisahkan), sehingga penelitian kualitatif tidak akan menetapkan penelitiannya hanya berdasarkan variabel penelitian, akan tetapi, seluruh situasi sosial yang diteliti berdasarkan aspek tempat (place), pelaku (actor), dan aktivitas (activity) yang saling berkaitan satu sama lain.

\section{Gambar 1}

\section{Situasi Sosial (social situation) ${ }^{6}$}

Tempat (place)

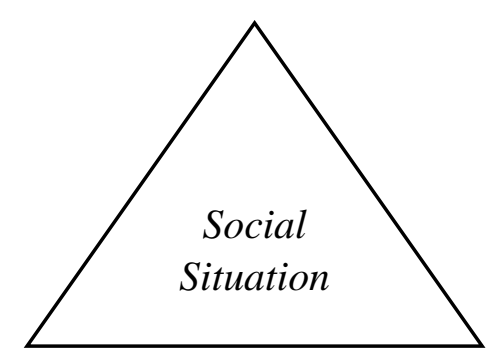

$$
\text { Pelaku (actor) Aktivitas (activity) }
$$

Adapun partisipan dalam penelitian ini adalah penanggungjawab bidang akademik, ketua program studi Usaha Perjalanan Wisata, seorang dosen pengajar mata kuliah bahasa Arab dan seluruh mahasiswa jurusan Usaha Perjalanan Wisata STIE Pariwisata Bandung yang mengikuti proses pembelajaran bahasa Arab semester empat tahun ajaran 2016/2017. Secara lebih spesifik, mahasiswa yang dimaksud terdiri dari

5 M.Khasairi. "Pengembangan komponen pembelajaran bahasa Arab di Madrasah Aliyah". Jurnal bahasa dan seni. 2013, 61.

6 Sugiyono. Metode Penelitian Pendidikan Pendekatan Kuantitatif, Kualitatif, dan R\&D. (Bandung: Alfabeta, 2013),298. 
sebelas orang, yakni 2 orang mahasiswi dan 9 orang mahasiswa. Data yang sudah terkumpul dianalisis dan dipaparkan secara deskriptif.

\section{Hasil Penelitian dan Pembahasan}

Di bawah ini merupakan pemaparan hasil penelitian dan pembahasan. Hasil di bawah ini mengenai perencanaan yang terjadi dalam proses pembelajaran bahasa Arab di Program studi Usaha Perjalanan Wisata STIE Pariwisata YAPARI. Adapun penemuan di bawah ini merupakan penjelasan dari hasil studi dokumentasi dan diperkuat oleh wawancara yang dilakukan terhadap para partisipan, yakni penanggung jawab bidang akademik, ketua program studi, dosen, dan mahasiswa. Fenomena yang dikupas dalam penemuan berikut ini berkaitan dengan kelengkapan perangkat perencanaan pembelajaran, komponen perencanaan pembelajaran, visi misi lembaga, kurikulum, rencana pembelajaran semester (RPS), dan manajemen akademik.

\section{Kelengkapan Perangkat Perencanaan Pembelajaran}

Berikut ini hasil studi dokumentasi yang mengupas tentang kelengkapan perencanaan pembelajaran bahasa Arab di program studi Usaha Perjalanan Wisata STIE Pariwisata YAPARI. Penjelasan hal tersebut dipaparkan sebagai berikut.

Tabel 1. Kelengkapan Perencanaan Pembelajaran

\begin{tabular}{cccc}
\hline & & \multicolumn{2}{c}{ Keterangan } \\
\cline { 3 - 4 } No & Aspek yang Ditelaah & Ada & Tidak \\
\hline 1 & Program tahunan & \multicolumn{1}{c}{} \\
\hline 2 & Program semseter & $\sqrt{ }$ \\
\hline 3 & Silabus & \multicolumn{2}{c}{} \\
\hline 4 & RPS & $\sqrt{ }$ \\
\hline
\end{tabular}

Diadaptasi dari: "Manajemen Pembelajaran di SMK Negeri 2 Semarang". Sebuah jurnal yang ditulis oleh Thomas (2011)

Berdasarkan tabel 1 di atas dengan merujuk pada komponen perangkat perencanaan pembelajaran yang diadaptasi dari Thomas, terdapat empat aspek yang berkaitan dengan kelengkapan perencanaan pembelajaran bahasa Arab di STIE Pariwisata YAPARI. Keempat aspek tersebut adalah program tahunan, program semester, silabus, dan RPS. Berdasarkan tabel tersebut dapat diketahui bahwa dosen sudah melakukan perencanaan pembelajaran bahasa Arab di STIE Pariwisata dengan cukup baik. Hal itu dibuktikan dengan adanya silabus dan RPS dalam kegiatan perencanaan pembelajaran yang dilakukan oleh dosen. sebagaimana diungkapkan oleh Thomas bahwa seorang pendidik diwajibkan membuat Program Tahunan (Prota), Program Semester (Promes), Silabus dan RPP yang dibuat pada awal tahun dan awal semester dengan mengacu pada Standar Kompetensi dan Kompetensi Dasar $(\mathrm{SKKD})^{7}$

Berdasarkan tabel di atas, diketahui bahwa tidak terdapat program tahunan dan program semester dalam perencanaan pembelajaran bahasa Arab di STIE Pariwisata.

${ }^{7}$ Partono Thomas. "Manajemen Pembelajaran di SMK Negeri 2 Semarang”. Jurnal Pendidikan Ekonomi Dinamika Pendidikan. 2011, 20. 
Tidak adanya program tahunan dalam kelengkapan perencanaan pembelahjaran bahasa Arab dapat dipahami, mengingat mata kuliah bahasa Arab hanya ada satu semester dalam satu tahun. Dan adanya silabus sudah dianggap cukup, sehingga dosen tidak membuat program semester.

\section{Komponen Perencanaan Pembelajaran}

Berikut ini adalah hasil studi dokumentasi tentang komponen perencanaan pembelajaran bahasa Arab di program studi Usaha Perjalanan Wisata STIE Pariwisata YAPARI. Penjelasan hal tersebut dipaparkan di bawah ini.

Tabel 2. Kelengkapan Komponen Perencanaan Pembelajaran

\begin{tabular}{|c|c|c|c|}
\hline \multirow[t]{2}{*}{ No } & \multirow[t]{2}{*}{ Aspek yang Ditelaah } & \multicolumn{2}{|c|}{ Keterangan } \\
\hline & & Ada & Tidak \\
\hline 1 & Perumusan tujuan pembelajaran & $\sqrt{ }$ & \\
\hline 2 & Penentuan alokasi waktu & $\sqrt{ }$ & \\
\hline 3 & Penentuan bahan/materi ajar & $\sqrt{ }$ & \\
\hline 4 & Penentuan media pembelajaran & $\sqrt{ }$ & \\
\hline 5 & Penentuan metode pembelajaran & $\sqrt{ }$ & \\
\hline
\end{tabular}

Berdasarkan tabel 2 di atas dengan merujuk pada komponen perangkat perencanaan pembelajaran yang diadaptasi dari Majid, terdapat lima aspek yang berkaitan dengan komponen perencanaan pembelajaran bahasa Arab di STIE Pariwisata YAPARI. Kelima aspek tersebut adalah perumusan tujuan pembelajaran, penentuan alokasi waktu, penentuan bahan/materi ajar, penentuan media pembelajaran, dan penentuan metode pembelajaran. Berdasarkan tabel tersebut dapat diketahui bahwa dosen sudah melakukan perencanaan pembelajaran bahasa Arab di STIE Pariwisata YAPARI dengan baik. Hal tersebut dapat itu dibuktikan dengan adanya komponen-komponen perencanaan pembelajaran yang meliputi perumusan tujuan pembelajaran, penentuan alokasi waktu, penentuan bahan/materi ajar, penentuan media pembelajaran, dan penentuan metode pembelajaran dalam silabus dan RPS yang dibuat oleh dosen.

Keberadaan komponen-komponen tersebut dalam perencanaan pembelajaran sebagaimana diungkapkan oleh pendapat Majid bahwa dalam konteks pengajaran, perencanaan dapat diartikan sebagai serangkaian proses untuk menyusun bahan ajar, media, metode, pendekatan, dan penilaian dalam durasi waktu tertentu untuk mencapai suatu target. ${ }^{8}$

\section{Visi misi lembaga}

Berikut ini adalah data hasil wawancara yang mengupas fenomena tentang visi misi lembaga. Penjelasan-penjelasan temuan tersebut dipaparkan di bawah ini.

Tabel 3. Visi Misi Lembaga

\begin{tabular}{lllllll}
\hline No. & Pertanyaan & Partisipan & Jawaban & & \\
\hline 1 & $\begin{array}{l}\text { Apakah visi/misi } \\
\text { lembaga? }\end{array}$ & $\begin{array}{l}\text { Penanggung } \\
\text { Jawab }\end{array}$ & $\begin{array}{l}\text { Menjadi pusat diklat } \\
\text { pariwisata. }\end{array}$ & dan & pengkajian \\
\hline
\end{tabular}

8 Abdul Majid. Perencanaan Pembelajaran: Mengembangkan Standar Kompetensi Guru, (Bandung: Remaja Rosdakarya, 2011), 11. 
Arabiyât Jurnal Pendidikan Bahasa Arab dan Kebahasaaraban, 5 (1), 2018

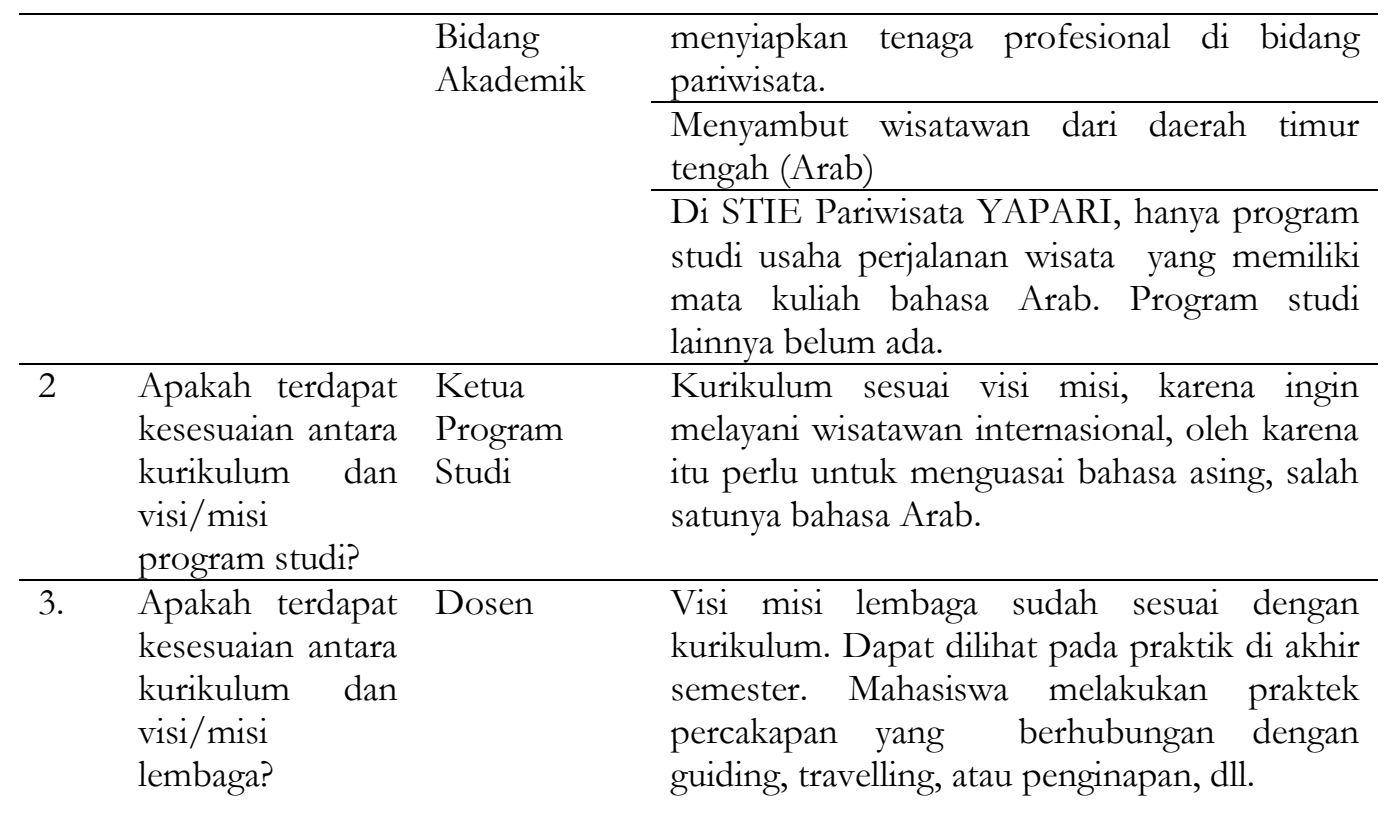

Berdasarkan tabel 3, ada tiga partisipan yang memberikan pemaparan terkait visi dan misi lembaga. Ketiga partisipan tersebut adalah penanggung jawab bidang akademik, ketua Program Studi, dan dosen. Penanggung jawab bidang akademik membahas mengenai empat pemaparan yang berkaitan dengan visi dan misi lembaga. Penanggung jawab bidang akademik memaparkan bahwa visi dan misi lembaga adalah agar kampus menjadi pusat diklat dan pengkajian pariwisata. Hal tersebut memang dapat dimaklumi, sebab kampus tersebut hingga saat ini masih menjadi satu-satunya kampus pariwisata yang memiliki mata kuliah bahasa Arab di Bandung. Tidak tertutup kemungkinan, bila kedepannya kampus tersebut menjadi kampus percontohan terkait pengajaran bahasa Arab untuk tujuan pariwisata. Hal ini sesuai dengan teori Hamalik yang membahas tujuan pendidikan dalam empat tingkatan, yakni: (1) tujuan pendidikan nasional; (2) tujuan lembaga pendidikan; (3) tujuan kurikulum; (4) tujuan mata pelajaran. ${ }^{9}$

Visi dan misi lembaga yang dipaparkan oleh penanggung jawab bidang akademik sesuai dengan poin 2 hingga 4 yang dipaparkan oleh Hamalik, yakni setiap lembaga pendidikan memiliki tujuan yang akan dicapai dan bisa jadi berbeda antara satu lembaga dan lembaga lainnya. ${ }^{10}$ Tujuan atau visi misi lembaga agar kampus menjadi pusat diklat dan pengkajian pariwisata bisa termasuk dalam poin 2 (tujuan lembaga pendidikan). Visi dan misi lembaga STIE Pariwisata YAPARI pun selaras dengan inti pembukaan UUD 45 dalam hal ini melaksanakan pendidikan yang dikategorikan oleh Hamalik (2010) dalam poin 3 (tujuan kurikulum) ${ }^{11}$. Seperti dipahami bersama bahwa kampus menjadi pusat diklat dan pengkajian pariwisata tentu berkorelasi erat dengan

\footnotetext{
${ }^{9}$ Oemar Hamalik. Proses belajar mengajar, (Jakarta: PT. Bumi Aksara, 2010).

${ }^{10}$ Oemar Hamalik. Proses belajar mengajar, (Jakarta: PT. Bumi Aksara, 2010).

11Oemar Hamalik. Proses belajar mengajar, (Jakarta: PT. Bumi Aksara, 2010).
} 
pelaksanaan pendidikan yang merupakan pengejawantahan dari pembukaan UUD 45 tersebut. Poin 4 tentang tujuan mata pelajaran merupakan penjabaran dari tujuan kurikulum dalam rangka tercapainya tujuan pendidikan nasional, diejawantahkan dengan baik dalam visi dan misi lembaga STIE Pariwisata YAPARI tersebut. Dengan diadakannya mata kuliah Bahasa Arab untuk tujuan khusus di kampus yang berbasis pariwisata, membantu pemerintah untuk mencerdaskan anak bangsa.

Penanggung jawab bidang akademik STIE Pariwisata YAPARI membahas tentang visi dan misi lembaga dalam menyiapkan tenaga profesional di bidang pariwisata. Menyiapkan tenaga profesional di bidang pariwisata sesuai dengan definisi pendidikan yang dipaparkan oleh Sauri bahwa pendidikan merupakan rekayasa terencana, terarah, dan terkendali yang dilakukan oleh mereka yang memiliki pengaruh (individu atau kelompok/lembaga) dalam mempengaruhi individu-individu lain agar memiliki kemampuan untuk mengaktualisasikan seluruh potensi yang dimilikinya, yang berupa -budi, cipta, rasa, karsa, dan karya- sehingga dapat menjadi individu yang mandiri, bertanggung jawab, dan berakhlak. ${ }^{12}$

Para pemangku kebijakan di lembaga menggali potensi para peserta didik agar menjadi tenaga profesional dalam bidang pariwisata. Salah satu upaya yang dilakukan adalah dengan mengaktualisasikan potensi berbahasa Arab sehingga diharapkan mereka dapat menjadi individu yang mandiri, bertanggung jawab, dan berakhlak. Terkait visi dan misi lembaga dalam menyiapkan tenaga profesional di bidang pariwisata, bagian akademik STIE Pariwisata YAPARI dan Undang-Undang Sistem Pendidikan Nasional (UU SISDIKNAS) pasal 1 nomor 20 tahun 2003 turut memperkuat tujuan tersebut, yakni:

"Pendidikan nasional berfungsi mengembangkan kemampuan dan membentuk watak serta peradaban bangsa yang bermartabat dalam rangka mencerdaskan kehidupan bangsa, bertujuan untuk mengembangkan potensi peserta didik agar menjadi manusia yang beriman dan bertakwa kepada Tuhan yang Maha Esa, berakhlak mulia, sehat, berilmu, cakap, kreatif, mandiri, dan menjadi warga negara yang demokratis serta bertanggung jawab". ${ }^{13}$

STIE Pariwisata YAPARI berusaha turut mencerdaskan kehidupan bangsa dengan menyiapkan tenaga profesional di bidang pariwisata. STIE Pariwisata YAPARI pun berupaya turut mengembangkan potensi peserta didik agar kreatif dan mandiri, di antaranya dengan menghadirkan mata kuliah bahasa Arab sebagai salah satu keterampilan yang menunjang kecerdasan mereka.

Pada wawancara dengan penanggung jawab bidang akademik, diinformasikan bahwa visi dan misi lembaga juga untuk menyambut wisatawan dari daerah timur tengah (Arab). Setiap tahunnya banyak turis berdatangan dari berbagai penjuru dunia, khususnya Timur Tengah menuju Indonesia. Semakin banyak orang yang melakukan perjalanan wisata ke Indonesia, maka semakin banyak pula para pelaku bisnis yang membangun fasilitas guna menunjang kebutuhan para wisatawan. Menurut Hutasoit \&

${ }^{12}$ Sofyan Sauri, et al. Filsafat ilmu pendidikan agama, (Bandung: Arfino Raya, 2010), 90.

13 Undang-Undang No. 20 Tahun 2003 tentang Sistem Pendidikan Nasional. 
Sari, ditinjau dari segi ekonomi maka kegiatan pariwisata dapat memberikan sumbangan terhadap penerimaan daerah yang bersumber dari pajak, retribusi parkir dan karcis atau dapat mendatangkan devisa dari para wisatawan mancanegara yang berkunjung. ${ }^{14}$ Hal ini sejalan dengan visi misi lembaga dalam menyambut wisatawan dari daerah timur tengah (Arab). Maka, mata kuliah Bahasa Arab untuk tujuan khusus pariwisata menjadi salah satu aspek yang penting dalam mendukung visi misi lembaga STIE Pariwisata YAPARI.

Visi dan misi STIE Pariwisata YAPARI tentang menyambut wisatawan dari daerah timur tengah (Arab) sesungguhnya berdampak besar pada aspek peningkatan wisatawan timur tengah yang hadir ke Indonesia. Hal tersebut sebagaimana yang diungkapkan oleh Kurt, et al. bahwa peningkatan kemampuan komunikasi dan keterampilan bekerja akan berpengaruh terhadap peningkatan jumlah wisatawan. ${ }^{15}$ Sehingga, bilamana STIE Pariwisata YAPARI berhasil menjadi prototipe dalam bidang pengajaran bahasa Arab untuk tujuan pariwisata, maka akan besar pula peluang STIE Pariwisata YAPARI menjadi kampus percontohan yang turut berkontribusi dalam peningkatan jumlah wisatawan timur tengah ke Indonesia.

Dari informasi penanggung jawab bidang akademik, ada tiga program studi di STIE Pariwisata YAPARI. Namun, hanya program studi Usaha Perjalanan Wisata yang memiliki mata kuliah bahasa Arab. Dalam faktanya, memang masih ada anggapan bahwa bahasa Arab dipelajari di lembaga pendidikan sebagai alat bantu investigasi tekstual dalam memahami nash-nash dan teks peradaban, juga untuk memahami ajaran agama. ${ }^{16}$ Sesuatu hal yang belum lumrah bagi program studi umum (tidak berfokus untuk memahami agama) untuk mempelajari bahasa Arab. Bahasa Arab yang diajarkan pada peserta didik di Program Studi Usaha Perjalanan Wisata, tidak menjadikan bahasa Arab sebagai bahasa harian. Berbeda halnya dengan para peserta didik di perguruan tinggi berbasis Islam sebagaimana yang diungkapkan oleh Bulkisah bahwa khusus pada jalur pendidikan Sekolah Agama Islam yang terdiri dari Madrasah Ibtidaiyah (MI), Madrasah Tsanawiyah hingga pada tingkat Perguruan Tinggi Agama Islam, bahasa Arab telah menjadi konsumsi bagi para siswa dan mahasiswa. ${ }^{17}$ Oleh karena itu, kenyataan bahwa hanya program studi Usaha Perjalanan Wisata yang memiliki mata kuliah bahasa Arab dan program studi lainnya belum ada. rasanya cukup logis. Lebih jauhnya, langkah tersebut menjadi sebuah inovasi dan terobosan yang berani dilakukan oleh STIE Pariwisata YAPARI yang memang memiliki visi dan misi untuk menyambut wisatawan asing, di antaranya yang berasal dari daerah timur tengah (Arab).

${ }^{14}$ Atin Baoa Rorizki Hutasoit \& Raina Linda Sari. "Analisis Permintaan Wisatawan Mancanegara Berwisata di Tuktuk Siadong, Kabupaten Samosir" Jurnal Ekonomi dan Keuangan. 2014, 587.

${ }^{15}$ Kurt a, Stahura. "Emergency planning and recovery for terror situations: an analysis with special reference to tourism". Jurnal Worldwide Hospitality and Tourism Themes. Vol. 4 Iss: 1, 2012.

16 Fathul Mujib. Rekonstruksi pendidikan bahasa Arab: dari pendekatan konvensional ke intrgratif bumanis. (Yogyakarta: Pedagogia, 2010), 74.

${ }^{17}$ Bulkisah. "Pembelajaran bahasa Arab pada perguruan tinggi agama Islam di Indonesia". Jurnal ilmiah DID AKTIKA. Vol. XII NO. 2, 2012, 309. 
Berdasarkan Tabel 3, ketua Program Studi memaparkan bahwa kurikulum sesuai visi misi, karena kan ingin melayani wisatawan internasional, oleh karena itu perlu untuk menguasai bahasa asing, salah satunya bahasa Arab.Kurikulum memegang peranan besar dalam program studi Usaha Perjalanan Wisata STIE Pariwisata YAPARI. Sebagaimana dipaparkan oleh Bahri bahwa kurikulum memiliki peran yang strategis dalam pendidikan. Karena secara umum kurikulum merupakan penjabaran dari visi, misi, serta tujuan pendidikan suatu bangsa. Kurikulum menjadi sangat fundamental karena menjadi ujung tombak dari pengimplementasian visi dan misi lembaga. ${ }^{18}$ Teori di atas memberikan penguatan betapa pentingnya kurikulum mata kuliah Bahasa Arab untuk tujuan khusus pariwisata agar sesuai dengan visi misi lembaga yakni melayani wisatawan internasional. Keselarasan antara kurikulum program dan visi misi lembaga dapat saling menguatkan satu sama lain sehingga peserta didik diharapkan bisa menjadi tenaga professional yang terampil, khususnya dalam melayani wisatawan mancanegara dari Timur Tengah.

Berdasarkan Tabel di atas, dosen memaparkan bahwa visi misi lembaga sudah sesuai dengan kurikulum. Dapat dilihat pada praktik di akbir semester. Mabasiswa melakukan praktek percakapan yang berhubungan dengan guiding, travelling, atau penginapan, dll. Kampus tersebut berusaha menghubungkan antara Program Studi Usaha Perjalanan Wisata dengan spesialisasi yang harus dimiliki oleh lulusan. Hal tersebut sesuai teori Majid khususnya pada poin mengenai tujuan yang diharapkan atau bagaimana cara mengorganisasi aktivitas belajar dan layanan-layanan pendukungnya; program dan layanan, atau bagaimana cara mengorganisasi aktivitas belajar dan layanan-layanan pendukungnya; tenaga manusia, mencakup cara-cara mengembangkan prestasi, spesialisasi, perilaku, kompetensi, maupun keputusan mereka; dan konteks sosial atau elemen-elemen lainnya yang perlu dipertimbangkan dalam perencanaan pengajaran. ${ }^{19}$

\section{Kurikulum}

Berikut ini adalah data hasil wawancara yang membahas fenomena tentang kurikulum STIE Pariwisata YAPARI. Penjelasan-penjelasan temuan tersebut dipaparkan di bawah ini.

\section{Tabel 4. Kurikulum}

\begin{tabular}{llllll}
\hline No. & Pertanyaan & & Partisipan & Jawaban & \\
\hline 1 & Apakah terdapat kurikulum & Penanggung & Kurikulum diserahkan kepada \\
untuk mata kuliah bahasa & Jawab & $\begin{array}{l}\text { dosen yang bersangkutan, dan } \\
\text { disesuaikan dengan visi misi } \\
\text { Arab di Jurusan Usaha }\end{array}$ & Bidang & & \\
& $\begin{array}{l}\text { Perjalanan Wisata STIE } \\
\text { Pariwisata? }\end{array}$ & & & & \\
& & & & & \\
\hline 2 & Apakah terdapat kurikulum & Ketua & Ada. Kurikulum tersedia dari \\
& untuk mata kuliah bahasa & Program & manajemen STIEPAR & \\
\hline
\end{tabular}

18 Syamsul Bahri. "Pengembangan kurikulum dasar dan tujuannya". Jurnal Ilmiah ISLAM FUTURA. Vol XI, No.1, 2011.

19 Abdul Majid. Perencanaan Pembelajaran: Mengembangkan Standar Kompetensi Guru, (Bandung: Remaja Rosdakarya, 2011),20. 


\begin{tabular}{|c|c|c|c|}
\hline & $\begin{array}{lrr}\text { Arab di } & \text { Jurusan } & \text { Usaha } \\
\text { Perjalanan } & \text { Wisata } & \text { STIE } \\
\text { Pariwisata? } & & \\
\end{array}$ & Studi & \\
\hline 3. & $\begin{array}{l}\text { Apakah terdapat kurikulum } \\
\text { untuk mata kuliah bahasa } \\
\text { Arab di Jurusan } \\
\text { Perjalanan } \\
\text { Pariwisata? }\end{array}$ & Dosen & $\begin{array}{l}\text { Kalau kurikulum } \\
\text { KEMENPAR atau DIKNAS } \\
\text { tidak ada. Namun kampus } \\
\text { memberikan wewenang kepada } \\
\text { dosen bahasa Arab untuk } \\
\text { membuat sendiri. Karena } \\
\text { memang tidak acuan ataupun } \\
\text { contoh bahasa Arab khusus } \\
\text { untuk pariwisata. Kalau bahasa } \\
\text { Arab nya sudah banyak. Di UPI } \\
\text { juga banyak, bisa di catut juga, } \\
\text { atau di manapun bisa. Tapi } \\
\text { masalahnya ini adalah bahasa } \\
\text { Arab khusus untuk pariwisata. } \\
\text { Dan dosen belum menemukan } \\
\text { kurikulum bahasa Arab untuk } \\
\text { pariwisata di tempat lain, oleh } \\
\text { karena itu dosen membuat } \\
\text { kurikulum sendiri. }\end{array}$ \\
\hline 4 & $\begin{array}{l}\text { Sebagai seorang peserta didik, } \\
\text { apa harapan atau ekspektasi } \\
\text { Anda terhadap perencanaan } \\
\text { pembelajaran Bahasa Arab? }\end{array}$ & Mahasiswa 1 & $\begin{array}{l}\text { Harapan / ekspektasi terhadap } \\
\text { perencanaan pembelajaran } \\
\text { bahasa Arab yang disusun oleh } \\
\text { dosen bahasa Arab adalah dapat } \\
\text { berkomunikasi langsung dengan } \\
\text { orang Arab. }\end{array}$ \\
\hline 5 & $\begin{array}{l}\text { Apa saja kebutuhan Anda } \\
\text { sebagai peserta didik terhadap } \\
\text { mata kuliah bahasa Arab? }\end{array}$ & & $\begin{array}{l}\text { Kebutuhan M1 terhadap mata } \\
\text { kuliah bahasa Arab adalah ingin } \\
\text { mengetahui kosakata bahasa } \\
\text { Arab dan adat istiadatnya. }\end{array}$ \\
\hline 6 & $\begin{array}{l}\text { Konten apa dalam mata } \\
\text { kuliah bahasa Arab yang ingin } \\
\text { Anda kuasai setelah } \\
\text { menyelesaikan sks? }\end{array}$ & & $\begin{array}{l}\text { Materi yang ingin M1 kuasai } \\
\text { setelah menyelesaikan sks adalah } \\
\text { percakapan penting di bandara, } \\
\text { seperti mengurus passport, dll. }\end{array}$ \\
\hline 7 & $\begin{array}{l}\text { Sebagai seorang peserta didik, } \\
\text { apa harapan atau ekspektasi } \\
\text { Anda terhadap perencanaan } \\
\text { pembelajaran Bahasa Arab? }\end{array}$ & Mahasiswa 2 & $\begin{array}{l}\text { Harapan/ekspektasi terhadap } \\
\text { perencanaan pembelajaran } \\
\text { bahasa Arab yang disusun oleh } \\
\text { dosen bahasa Arab adalah dapat } \\
\text { membimbing dalam } \\
\text { pembelajaran bahasa Arab }\end{array}$ \\
\hline 8 & $\begin{array}{l}\text { Apa saja kebutuhan Anda } \\
\text { sebagai peserta didik terhadap } \\
\text { mata kuliah bahasa Arab? }\end{array}$ & & $\begin{array}{l}\text { Kebutuhan M2 sebagai peserta } \\
\text { didik adalah mengerti bahasa } \\
\text { Arab dan bisa mengucapkan } \\
\text { bahasa arab }\end{array}$ \\
\hline 9 & $\begin{array}{l}\text { Konten apa dalam mata } \\
\text { kuliah bahasa Arab yang ingin }\end{array}$ & & $\begin{array}{l}\text { Materi yang ingin dikuasai } \\
\text { setelah menyelesaikan sks adalah }\end{array}$ \\
\hline
\end{tabular}


Arabiyât Jurnal Pendidikan Bahasa Arab dan Kebahasaaraban, 5 (1), 2018

\begin{tabular}{|c|c|c|c|}
\hline & $\begin{array}{l}\text { Anda kuasai } \\
\text { menyelesaikan sks? }\end{array}$ & & percakapan bahasa Arab. \\
\hline 10 & $\begin{array}{l}\text { Sebagai seorang peserta didik, } \\
\text { apa harapan atau ekspektasi } \\
\text { Anda terhadap perencanaan } \\
\text { pembelajaran Bahasa Arab? }\end{array}$ & \multirow{3}{*}{ Mahasiswa 3} & $\begin{array}{l}\text { Harapannya agar bahasa Arab } \\
\text { bisa menjadi jembatan } \\
\text { komunikasi antara orang } \\
\text { Indonesia dan orang Arab. }\end{array}$ \\
\hline 11 & $\begin{array}{l}\text { Apa saja kebutuhan Anda } \\
\text { sebagai peserta didik terhadap } \\
\text { mata kuliah bahasa Arab? }\end{array}$ & & $\begin{array}{l}\text { Kebutuhan peserta didik M3 } \\
\text { adalah listening, pelatihan } \\
\text { pronounciation, lebih banyaknya } \\
\text { latihan berbicara. }\end{array}$ \\
\hline 12 & $\begin{array}{l}\text { Konten apa dalam mata } \\
\text { kuliah bahasa Arab yang ingin } \\
\text { Anda kuasai setelah } \\
\text { menyelesaikan sks? }\end{array}$ & & $\begin{array}{l}\text { Materi tentang daily live di Arab/ } \\
\text { komunikasi sehari-hari. }\end{array}$ \\
\hline 13 & $\begin{array}{l}\text { Sebagai seorang peserta didik, } \\
\text { apa harapan atau ekspektasi } \\
\text { Anda terhadap perencanaan } \\
\text { pembelajaran Bahasa Arab? }\end{array}$ & \multirow[t]{3}{*}{ Mahasiswa 4} & $\begin{array}{l}\text { Agar bisa lebih tahu bahasa } \\
\text { Arab. }\end{array}$ \\
\hline 14 & $\begin{array}{l}\text { Apa saja kebutuhan Anda } \\
\text { sebagai peserta didik terhadap } \\
\text { mata kuliah bahasa Arab? }\end{array}$ & & Lebih banyak interaksi \\
\hline 15 & $\begin{array}{l}\text { Konten apa dalam mata } \\
\text { kuliah bahasa Arab yang ingin } \\
\text { Anda kuasai setelah } \\
\text { menyelesaikan sks? }\end{array}$ & & Perbanyak percakapan. \\
\hline 16 & $\begin{array}{l}\text { Sebagai seorang peserta didik, } \\
\text { apa harapan atau ekspektasi } \\
\text { Anda terhadap perencanaan } \\
\text { pembelajaran Bahasa Arab? }\end{array}$ & \multirow{3}{*}{ Mahasiswa 5} & $\begin{array}{l}\text { Harapan M5 agar cara } \\
\text { pembelajarannya simpel }\end{array}$ \\
\hline 17 & $\begin{array}{l}\text { Apa saja kebutuhan Anda } \\
\text { sebagai peserta didik terhadap } \\
\text { mata kuliah bahasa Arab? }\end{array}$ & & $\begin{array}{l}\text { Butuh banyak interaksi } \\
\text { percakapan }\end{array}$ \\
\hline 18 & $\begin{array}{l}\text { Konten apa dalam mata } \\
\text { kuliah bahasa Arab yang ingin } \\
\text { Anda kuasai setelah } \\
\text { menyelesaikan sks? }\end{array}$ & & Interaksi percakapan \\
\hline 19 & $\begin{array}{l}\text { Sebagai seorang peserta didik, } \\
\text { apa harapan atau ekspektasi } \\
\text { Anda terhadap perencanaan } \\
\text { pembelajaran Bahasa Arab? }\end{array}$ & \multirow[t]{3}{*}{ Mahasiswa 6} & $\begin{array}{l}\text { Agar bisa berbahasa Arab dan } \\
\text { berbicara dengan wisatawan asal } \\
\text { Arab }\end{array}$ \\
\hline 20 & $\begin{array}{l}\text { Apa saja kebutuhan Anda } \\
\text { sebagai peserta didik terhadap } \\
\text { mata kuliah bahasa Arab? }\end{array}$ & & Visualisasi \\
\hline 21 & $\begin{array}{l}\text { Konten apa dalam mata } \\
\text { kuliah bahasa Arab yang ingin } \\
\text { Anda kuasai setelah } \\
\text { menyelesaikan sks? }\end{array}$ & & Percakapan dengan bahasa Arab \\
\hline
\end{tabular}




Sebagai seorang peserta didik,
apa harapan atau ekspektasi
Anda terhadap perencanaan
pembelajaran Bahasa Arab?

\begin{tabular}{ll}
\hline 23 & $\begin{array}{l}\text { Apa saja kebutuhan Anda } \\
\text { sebagai peserta didik terhadap } \\
\text { mata kuliah bahasa Arab? }\end{array}$ \\
\hline 24 & $\begin{array}{l}\text { Konten apa dalam mata } \\
\text { kuliah bahasa Arab yang ingin }\end{array}$ \\
& Anda kuasai setelah \\
& menyelesaikan sks? \\
\hline $25 \quad$ & Sebagai seorang peserta didik, \\
& apa harapan atau ekspektasi \\
& Anda terhadap perencanaan \\
pembelajaran bahasa Arab?
\end{tabular}

26 Apa saja kebutuhan Anda sebagai peserta didik terhadap mata kuliah bahasa Arab?

27 Konten apa dalam mata kuliah bahasa Arab yang ingin Anda kuasai setelah menyelesaikan sks?

\begin{tabular}{|c|c|c|c|}
\hline 29 & $\begin{array}{l}\text { Sebagai seorang peserta didik, } \\
\text { apa harapan atau ekspektasi } \\
\text { Anda terhadap perencanaan } \\
\text { pembelajaran Bahasa Arab? }\end{array}$ & \multirow[t]{3}{*}{ Mahasiwa 9} & $\begin{array}{l}\text { Harapannya agar M9 bisa } \\
\text { mengerti bahasa Arab dan } \\
\text { bercakap-cakap dengan orang } \\
\text { arab menggunakan bahasa Arab }\end{array}$ \\
\hline 29 & $\begin{array}{l}\text { Apa saja kebutuhan Anda } \\
\text { sebagai peserta didik terhadap } \\
\text { mata kuliah bahasa Arab? }\end{array}$ & & $\begin{array}{l}\text { Butuh bisa percakapan karena } \\
\text { prodi M9 juga travel hingga lebih } \\
\text { membutuhkan bercakap-cakap. }\end{array}$ \\
\hline 30 & $\begin{array}{l}\text { Konten apa dalam mata } \\
\text { kuliah bahasa Arab yang ingin } \\
\text { Anda kuasai setelah } \\
\text { menyelesaikan sks? }\end{array}$ & & Percakapan \\
\hline 32 & $\begin{array}{l}\text { Sebagai seorang peserta didik, } \\
\text { apa harapan atau ekspektasi } \\
\text { Anda terhadap perencanaan } \\
\text { pembelajaran Bahasa Arab? }\end{array}$ & $\begin{array}{l}\text { Mahasiswa } \\
10\end{array}$ & $\begin{array}{l}\text { Harapannya agar bisa berbahasa } \\
\text { Arab dan } \\
\text { berkomunikasi dengan orang } \\
\text { Arab secara langsung bila kita } \\
\text { mengunjungi tanah suci Mekah }\end{array}$ \\
\hline
\end{tabular}

Harapannya agar pembelajaran bahasa Arab lebih menarik seperti melalui games, menonton video bagaimana orang Arab Mahasiswa 7 berkomunikasi agar M7 bisa berbicara dengan wisatawan arab jika ia menjadi tour guide.

Bisa berbicara

Tentang bilangan dan
percakapan Arab

Bahasa Arab kedepannya bisa membantu perekonomian travel, travel umroh, dan tak dipandang sebelah mata. Bahasa Arab semoga bisa membantu lebih Mahasiswa 8 khusyu para jamaah umrah. Semoga, bahasa Arab terpakai ketika kerja.

Kebutuhan untuk kerja di travel umroh, dan komunikasi ketika kerja

Reservasi tiket dan bicara. 


\begin{tabular}{lll}
\hline 34 & $\begin{array}{l}\text { Apa saja kebutuhan Anda } \\
\text { sebagai peserta didik terhadap } \\
\text { mata kuliah bahasa Arab? }\end{array}$ & Perbanyak kosakata \\
\hline 35 & $\begin{array}{l}\text { Konten apa dalam mata } \\
\text { kuliah bahasa Arab yang ingin }\end{array}$ & Percakapan \\
& Anda kuasai setelah & \\
menyelesaikan sks? & \\
\hline
\end{tabular}

Berdasarkan tabel 4, ada tiga belas partisipan yang memberikan pemaparan terkait kurikulum. Ketiga belas partisipan tersebut adalah penanggung jawab bidang akademik, ketua Program Studi, dosen, dan sepuluh mahasiswa. Penanggung jawab bidang akademik memaparkan bahwa kurikulum diserahkan kepada dosen yang bersangkutan dan disesuaikan dengan visi misi lembaga. Hal tersebut juga senada dengan yang diungkapkan oleh dosen bahwa Kalau kurikulum dari KEMENPAR atau DIKNAS tidak ada.

Namun kampus memberikan wewenang kepada dosen bahasa Arab untuk membuat sendiri. Karena memang tidak acuan ataupun contoh bahasa Arab khusus untuk pariwisata. kalau bahasa Arab nya sudah banyak. Di UPI juga banyak, bisa di catut juga, atau di manapun bisa. Tapi masalahnya ini adalah bahasa Arab khusus untuk pariwisata. Dan dosen belum menemukan kurikulum bahasa Arab untuk pariwisata di tempat lain, oleh karena itu dosen membuat kurikulum sendiri.

Hal ini membuat kurikulum memegang peranan penting dalam pengaplikasian visi dan misi lembaga. Kurikulum harus sejalan dengan visi dan misi lembaga. Apabila visi misi lembaga adalah tujuan besar yang ingin dicapai, maka seyogyanya kurikulum yang dibuat oleh dosen dapat menjabarkan tujuan dari lembaga tersebut. Kurikulum yang diserahkan kepada dosen yang bersangkutan dalam pembuatannya dan disesuaikan dengan visi misi lembaga. Kurikulum yang dibuat oleh dosen merupakan hal yang fundamental. Sebagaimana diungkapkan oleh Bahri bahwa kurikulum merupakan seperangkat rencana pembelajaran yang terdiri dari isi serta materi pembelajaran yang terstruktur, terprogram, dan terencana dengan baik yang berkaitan dengan berbagai kegiatan belajar mengajar dengan tujuan untuk mencapai tujuan pendidikan. $^{20}$

Sesungguhnya, kurikulum diserahkan kepada dosen yang bersangkutan dan disesuaikan dengan visi misi lembaga. Keberadaan kurikulum dapat memudahkan dosen dalam kegiatan belajar mengajar. Karena kurikulum dapat memberikan gambaran yang komperhensif mengenai langkah apa saja yang harus dilakukan dosen ketika kegiatan pembelajaran.

Lebih lanjut, informasi yang diungkapkan oleh ketua Program Studi bahwa kurikulum tersedia dari manajemen STIEPAR menunjukkan fenomena lain. Fenomena tersebut muncul secara tersirat bahwa meskipun dosen diberi keleluasaan sendiri untuk membuat kurikulum, namun ada kriteria khusus yang dimiliki oleh manajemen STIEPAR, sehingga dosen pun tetap dalam koridor yang sesuai dengan

20 Syamsul Bahri. "Pengembangan kurikulum dasar dan tujuannya". Jurnal Ilmiah ISLAM FUTURA. Vol XI, No.1, 2011, 19. 
visi dan misi lembaga. Manajemen STIEPAR menetapkan kompetensi pembelajaran yang perlu dicapai oleh dosen dan peserta didik. Seperti diungkapkan oleh Pribadi bahwa pembelajaran adalah suatu usaha yang dilakukan guna mendapatkan kompetensi yang berwujud pengetahuan, keterampilan, dan sikap yang diperlukan dalam melakukan suatu pekerjaan. ${ }^{21}$

Sementara itu, kompetensi pembelajaran yang diistilahkan oleh Ketua Program Studi sebagai dengan kurikulum yang tersedia memang harus direncanakan dengan matang. Kurikulum yang tersedia dari manajemen STIEPAR menjadi poin plus yang penting. Seperti diungkapkan oleh Supriadhi dan Darmawan bahwa hal tersebut karena pembelajaran (instruksional) merupakan suatu konsep dari dua kegiatan yang saling berkaitan (mengajar dan belajar) yang hendaknya direncanakan, diterapkan, serta diarahkan pada tercapainya tujuan sejumlah kompetensi tertentu dan hasil belajar yang dicapai dapat tergambar dari indikator yang sudah ditentukan. ${ }^{22}$

Berdasarkan tabel 4, ekspektasi Mahasiswa 1 terhadap perencanaan pembelajaran bahasa Arab yang disusun oleh dosen bahasa Arab adalah dapat berkomunikasi langsung dengan orang Arab. Harapan mahasiswa 1 sejalan dengan yang diungkapkan oleh mahasiswa 6 dan mahasiswa 9. Mahasiswa 6 dan 9 berharap dapat mengerti bahasa Arab dan berbicara dengan wisatawan asal arab. Mahasiswa 10 bahkan berharap bisa berbahasa Arab dan berkomunikasi dengan orang Arab secara langsung bila mengunjungi tanah suci Mekah. Hal ini memang menjadi sebuah kewajaran bagi seorang peserta didik untuk memiliki harapan menjadi individu yang memiliki potensi untuk berkembang, dan mereka berusaha mengembangkan potensinya itu melalui proses pendidikan pada jalur dan jenis pendidikan tertentu. ${ }^{23}$

Lebih lanjut, ekspekstasi mahasiswa 2 agak berbeda, ia lebih fokus pada dosen. Ia berharap dosen bahasa Arab dapat membimbing dalam pembelajaran bahasa Arab. Sedangkan ekspektasi mahasiswa 3 dalam mengembangkan potensinya adalah dengan mempelajari bahasa Arab bisa menjadi jembatan komunikasi antara orang Indonesia dan orang Arab. Ekspektasi mahasiswa 3 yang fokus pada keberadaan bahasa Arab itu sendiri cukup berkorelasi dengan harapan mahasiswa 8 yang mengungkapkan bahwa kemampuan berbahasa Arab bisa membantu perekonomian travel, travel umroh, dan tak dipandang sebelah mata, semoga bisa membantu para jamaah umroh untuk lebih khusyu beribadah. Semoga, bahasa Arab terpakai ketika kerja. Ekspektasi mahasiswa 4 dalam belajar bahasa Arab di Program Studi Usaha Perjalanan Wisata adalah bisa lebih tahu bahasa Arab. Keingintahuan mahasiswa 4 mendorong untuk mempelajari bahasa Arab dalam perkuliahan. Hal yang disoroti oleh mahasiswa 5 agak berbeda, ia berharap agar cara pembelajarannya simple. Keinginan mahasiswa 5 agar pembelajaran bahasa Arab tersebut sederhana dapat difahami. Karena tak semua mahasiswa memiliki latar belakang pendidikan yang sama. Hal ini diperkuat oleh pendapat Rochgiyanti bahwa 2012), 9 .

21 A.B Pribadi. Model desain sistem pembelajaran. (Jakarta: dian rakyat, 2010), iii.

22 D. Supriadie dan D. Darmawan. Komunikasi Pembelajaran. (Bandung: Remaja Rosdakarya,

23 M. Ramli. "Hakikat pendidik dan peserta didik". Jurnal Tarbiyah Islamiyah, vol 5, no 1, 2015, 68. 
"setiap peserta didik memiliki perbedaan, baik dalam kemampuan intelektual, kemampuan fisik, latar belakang keluarga, kebiasaan, maupun pendekatan belajar yang digunakan". ${ }^{24}$

Metode mengajar yang diharapkan oleh mahasiswa 7 agar pembelajaran bahasa Arab lebih menarik seperti melalui games, menonton video bagaimana orang Arab berkomunikasi agar bisa berbicara dengan wisatawan arab jika ia menjadi tour guide. Hal ini dikuatkan oleh pemaparan bahwa metode mengajar yang efektif melingkupi bermacam potensi/kemampuan, minat, karakteristik, pengalaman, kebutuhan, kebiasaaan, dan gaya belajar peserta didik. kondisi, potensi, tingkat kemampuan, minat, motivasi, masalah, gaya, dan kecepatan belajar peserta didik. ${ }^{25}$

Menurut Hartono, peserta didik pada dasarnya merupakan manusia yang sedang dalam masa pertumbuhan dan perkembangan, yang memerlukan bantuan dari orang lain (orang dewasa) untuk menjalani pertumbuhan dan perkembangannya tersebut. Peserta didik memiliki berbagai kebutuhan, yang dapat dikategorikan kepada kebutuhan pisik dan non fisik, di mana masing-masing kebutuhan harus terpenuhi dengan baik. ${ }^{26}$ Kebutuhan non fisik yang diperlukan terkait mata kuliah bahasa Arab oleh Mahasiswa 1 adalah kosakata bahasa Arab dan adat istiadatnya. Kebutuhan non fisik yang diperlukan terkait mata kuliah bahasa Arab oleh Mahasiswa 2 adalah mengerti dan bisa mengucapkan bahasa Arab. Mahasiswa 3 memerlukan listening, pelatihan pronounciation, dan lebih banyaknya latihan berbicara. Ungkapan mahasiswa 3 sejalan dengan mahasiswa 4 dan 5 yang ingin lebih banyak interaksi percakapan. Mereka pun senada dengan mahasiswa 10 yang ingin memperbanyak kosakata. Mahasiswa 6 lebih berarah pada media ajar yang kaya akan visualisasi. Mahasiswa 7 memiliki kebutuhan untuk bisa berbicara dalam bahasa Arab. Mahasiswa 8 dan Mahasiswa 9 sudah mulai visioner dengan memikirkan fungsi bahasa Arab sebagai kebutuhan untuk kerja di travel umroh, dan komunikasi ketika kerja.

Berdasarkan tabel 4, minat para mahasiswa terkait materi yanng akan dikuasai setelah selesai sks cukup bervariatif. Mahasiswa 1, 2, percakapan penting di bandara, seperti mengurus passport, dll. Hal tersebut senada dengan mahasiswa 8 yang ingin bisa berkomunikasi dalam bahasa Arab unntuk Reservasi tiket dan bicara. Mahasiswa 3, 8, 9, 10 memiliki pandangan agar mata kuliah bahasa Arab lebih mengggali materi tentang komunikasi sehari-hari. Sementara itu, Mahasiswa 4, 5, 6, dan 7 ingin mendalami interaksi percakapan. Dan Mahasiswa 7 menjelaskan tentang bilangan dan percakapan Arab.

${ }^{24}$ Rochgiyanti. "Pembelajaran paket B di PKBM Barito kota Banjarmasin". Jurnal pendidikan progresif. Vol 3, Nomor 2, 2013, hlm.173.

${ }^{25}$ D. Mulyasana. Pendidikan bermutu dan berdaya saing. (Bandung: Remaja Rosdakarya Offset, 2012)

${ }^{26}$ Hartono. "Pendidik dan peserta didik dalam perspektif filsafat pendidikan islam". Jurnal Potensial. Vol 13, 2014,hlm. 106. 


\section{Rencana Pembelajaran Semester (RPS)}

Berikut ini adalah data hasil wawancara yang mengupas fenomena tentang rencana pembelajaran semester (RPS) mata kuliah Bahasa Arab di Program Studi Usaha Perjalanan Wisata STIE Pariwisata YAPARI. Penjelasan-penjelasan temuan tersebut dipaparkan di bawah ini.

\section{Tabel 5. Rencana pembelajaran semester (RPS)}

\begin{tabular}{|c|c|c|c|}
\hline No. & Pertanyaan & Partisipan & Jawaban \\
\hline 1 & $\begin{array}{l}\text { Berapa jumlah sks untuk mata } \\
\text { kuliah bahasa Arab di jurusan } \\
\text { tersebut? Menurut Anda apakah } \\
\text { jumlah sks tersebut sudah } \\
\text { cukup? }\end{array}$ & \multirow[t]{2}{*}{$\begin{array}{l}\text { Penanggung } \\
\text { Jawab } \\
\text { Bidang } \\
\text { Akademik }\end{array}$} & $\begin{array}{l}2 \text { sks. sks kurang mencukupi. } \\
\text { Mungkin mereka harus lebih } \\
\text { banyak praktek pengucapan dan } \\
\text { ngobrol. }\end{array}$ \\
\hline 2 & $\begin{array}{l}\text { Apakah RPS disusun sesuai } \\
\text { dengan kurikulum? }\end{array}$ & & Tentu. RPS sesuai kurikulum \\
\hline 3 & 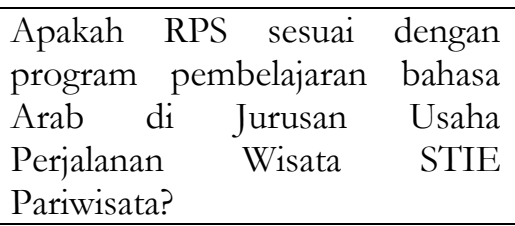 & & $\begin{array}{l}\text { RPS sesuai program } \\
\text { pembelajaran bahasa Arab. }\end{array}$ \\
\hline 4 & $\begin{array}{l}\text { Apakah terdapat pedoman wajib } \\
\text { dalam pembuatan RPS? }\end{array}$ & & $\begin{array}{l}\text { Cuma ada patokan. Belum ada } \\
\text { pedoman wajib. Berharap } 2 \text { sks } \\
\text { dalam satu semester mahasiswa } \\
\text { fasih bahasa Arab. }\end{array}$ \\
\hline
\end{tabular}

\begin{tabular}{|c|c|c|c|}
\hline 5 & $\begin{array}{l}\text { Apakah RPS disusun sesuai } \\
\text { dengan kurikulum? }\end{array}$ & \multirow{4}{*}{$\begin{array}{l}\text { Ketua } \\
\text { Program } \\
\text { Studi }\end{array}$} & $\begin{array}{l}\text { Prodi memiliki patokan sesuai } \\
\text { kurikulum, materi diserahkan } \\
\text { pada dosen }\end{array}$ \\
\hline 6 & $\begin{array}{l}\text { Apakah RPS sudah sesuai } \\
\text { dengan kebutuhan peserta didik? }\end{array}$ & & $\begin{array}{l}\text { RPS belum sesuai kebutuhan } \\
\text { peserta didik. Harus dievaluasi } \\
\text { kembali, agar lebih lancar dalam } \\
\text { percakapan. }\end{array}$ \\
\hline 7 & $\begin{array}{l}\text { Jika ada, kapankah evaluasi RPS } \\
\text { dilaksanakan? }\end{array}$ & & $\begin{array}{l}\text { Evaluasi RPS diadakan setahun } \\
\text { sekali pada jadwal rapat di } \\
\text { manajemen tentang kurikulum. }\end{array}$ \\
\hline 8 & $\begin{array}{lcc}\text { Apakah RPS } & \text { sesuai } & \text { dengan } \\
\text { program pembelajaran } & \text { bahasa } \\
\text { Arab di } & \text { Jurusan } & \text { Usaha } \\
\text { Perjalanan } & \text { Wisata } & \text { STIE } \\
\text { Pariwisata? } & & \\
\end{array}$ & & $\begin{array}{l}\text { RPS sudah sesuai dengan } \\
\text { program pembelajaran bahasa } \\
\text { Arab di Program Studi Usaha } \\
\text { Perjalanan Wisata }\end{array}$ \\
\hline 9 & $\begin{array}{l}\text { Apakah RPS disusun sesuai } \\
\text { dengan kurikulum? }\end{array}$ & & $\begin{array}{l}\text { RPS dibuat sesuai kurikulum. } \\
\text { Disampaikan kepada mahasiswa } \\
\text { secara lisan, bukan tertulis. } \\
\text { Mencakup pembelajaran yang } \\
\text { akan dilakukan selama satu } \\
\text { semester. }\end{array}$ \\
\hline
\end{tabular}




\begin{tabular}{|c|c|c|c|}
\hline 10 & $\begin{array}{l}\text { Apakah RPS sudah sesuai } \\
\text { dengan kebutuhan peserta didik? }\end{array}$ & Dosen & $\begin{array}{l}\text { RPS sudah seideal dan sesuai } \\
\text { dengan kebutuhan peserta didik. } \\
\text { Tapi praktek kadang berbeda. } \\
\text { Misalnya, satu materi } \\
\text { menghabiskan waktu tiga } \\
\text { pertemuan. Otomatis materi lain } \\
\text { tercancel. }\end{array}$ \\
\hline 11 & $\begin{array}{lcc}\text { Apakah RPS } & \text { sesuai } & \text { dengan } \\
\text { program pembelajaran } & \text { bahasa } \\
\text { Arab di } & \text { Jurusan } & \text { Usaha } \\
\text { Perjalanan } & \text { Wisata } & \text { STIE }\end{array}$ & & $\begin{array}{l}\text { Selama ini belum ada teguran } \\
\text { dari penanggung jawab bidang } \\
\text { akademik, maka RPS yang itu } \\
\text { masih dipergunakan. }\end{array}$ \\
\hline
\end{tabular}

12 Apakah RPS dijelaskan oleh dosen pada pertemuan pertama atau dilihat di laman kampus?

\begin{tabular}{|c|c|c|c|}
\hline 13 & $\begin{array}{l}\text { Apakah Anda pernah melakukan } \\
\text { survey untuk mengetahui } \\
\text { kebutuhan peserta didik tentang } \\
\text { pembelajaran bahasa Arab di } \\
\text { Jurusan Usaha Perjalanan Wisata } \\
\text { STIE Pariwisata? }\end{array}$ & & $\begin{array}{l}\text { Dosen belum melakukan survey } \\
\text { untuk mengetahui kebutuhan } \\
\text { peserta didik, selama ini hanya } \\
\text { konsultasi dengan bagian } \\
\text { akademik. }\end{array}$ \\
\hline 14 & $\begin{array}{l}\text { Apakah dosen menunjukkan / } \\
\text { memberikan / menjelaskan RPS } \\
\text { selama satu semester di awal } \\
\text { pekuliahan kepada Anda selaku } \\
\text { peserta didik? }\end{array}$ & Mahasiswa 1 & Dosen tidak menunjukkan RPS \\
\hline 15 & $\begin{array}{l}\text { Apakah dosen menunjukkan / } \\
\text { memberikan / menjelaskan RPS } \\
\text { selama satu semester di awal } \\
\text { pekuliahan kepada Anda selaku } \\
\text { peserta didik? }\end{array}$ & Mahasiswa 2 & Dosen tidak menunjukkan RPS \\
\hline 16 & $\begin{array}{l}\text { Apakah dosen menunjukkan / } \\
\text { memberikan / menjelaskan RPS } \\
\text { selama satu semester di awal } \\
\text { pekuliahan kepada Anda selaku } \\
\text { peserta didik? }\end{array}$ & Mahasiswa 3 & Dosen menjelaskan RPS \\
\hline 17 & $\begin{array}{l}\text { Apakah dosen menunjukkan / } \\
\text { memberikan / menjelaskan RPS } \\
\text { selama satu semester di awal } \\
\text { pekuliahan kepada Anda selaku } \\
\text { peserta didik? }\end{array}$ & Mahasiswa 4 & $\begin{array}{l}\text { Dosen tidak menjelaskan RPS. } \\
\text { Mahasiswa } 4 \text { mengira bahwa } \\
\text { bahasa Arab tersebut tentang } \\
\text { perkenalan Bahasa Arab dan } \\
\text { tulisan Arab dari dasar. }\end{array}$ \\
\hline 18 & $\begin{array}{l}\text { Apakah dosen menunjukkan / } \\
\text { memberikan / menjelaskan RPS }\end{array}$ & Mahasiswa 5 & Dosen tidak menunjukkan RPS \\
\hline
\end{tabular}

RPS tidak dilihat di website kampus. Di awal pertemuan, RPS dijelaskan tapi tidak secara rinci. Hanya secara global bahwa belajar bahasa Arab indikatornya mahasiswa harus bisa apa, nanti belajar apa, tugasnya, dan materinya.

Dosen belum melakukan survey untuk mengetahui kebutuhan peserta didik, selama ini hanya konsultasi dengan bagian pembelajaran bahasa Arab di Jurusan Usaha Perjalanan Wisata STIE Pariwisata? memberikan / menjelaskan RPS di awa peserta didik?

Apakah dosen menunjukkan / Mahasiswa 2 Dosen tidak menunjukkan RPS memberikan / menjelaskan RPS pekuliahan kepada Anda selaku peserta didik?

Apakah dosen menunjukkan selama satu semester di awal pekuliahan kepada Anda selaku peserta didik? Apakah dosen menunjukkan selama satu semester di awal pekuliahan kepada Anda selaku peserta didik? Mahasiswa 4 mengira bahwa bahasa Arab tersebut tentang perkenalan Bahasa Arab dan tulisan Arab dari dasar.

18 memberikan / menjelaskan RPS 
selama satu semester di awal pekuliahan kepada Anda selaku peserta didik?

Apakah dosen menunjukkan / Mahasiswa 6 Dosen menjelaskan RPS. Sangat memberikan / menjelaskan RPS

19 selama satu semester di awal membantu dalam pembelajaran pekuliahan kepada Anda selaku bahasa Arab. peserta didik?

Apakah dosen menunjukkan / Mahasiswa 7 Dosen tidak menunjukkan RPS, memberikan / menjelaskan RPS

20 selama satu semester di awal hanya menjelaskan apa saja yang pekuliahan kepada Anda selaku akan dipelajari. peserta didik?

Apakah dosen menunjukkan / Mahasiswa 8 Dosen tidak menjelaskan RPS. memberikan / menjelaskan RPS

21 selama satu semester di awal pekuliahan kepada Anda selaku peserta didik? Mahasiswa 8 menduga bahwa bahasa Arab tersebut tentang perkenalan, bilangan, dan Apakah dosen menunjukkan / Mahasiswa 9 Dosen menjelaskan RPS. memberikan / menjelaskan RPS Menurut Mahasiswa 9, hal

22 selama satu semester di awal pekuliahan kepada Anda selaku peserta didik?

Apakah dosen menunjukkan / Mahasiswa memberikan / menjelaskan RPS 23 selama satu semester di awal pekuliahan kepada Anda selaku peserta didik?

\section{0}

Berdasarkan tabel 5, ada tiga belas partisipan yang memberikan pemaparan terkait RPS. Ketiga partisipan tersebut adalah penanggung jawab bidang akademik, ketua Program Studi, dan dosen. Sedang sepuluh lainnya adalah para mahasiswa di Program Studi Usaha Perjalanan Wisata STIE Pariwisata YAPARI. Keseluruh informasi ini dikumpulkan sebagai cara untuk triangulasi. Penanggung jawab bidang akademik memaparkan lima poin yakni 2 sks. Jumlah sks kurang mencukupi, harus banyak praktek; RPS sudah sesuai dengan kurikulum; RPS telah sesuai program pembelajaran bahasa Arab; menekankan penguasaan kompetensi bahasa Arab; dan Berharap 2 sks dalam satu semester mahasiswa fasih dalam bahasa Arab.

Berdasarkan tabel 5, ketua Program Studi mengemukakan bahwa prodi memiliki patokan sesuai kurikulum, sedangkan materi diserahkan pada dosen; namun sayangnya RPS belum sesuai kebutuhan peserta didik. Harus dievaluasi kembali, agar lebih lancar dalam percakapan; evaluasi RPS diadakan setahun sekali pada jadwal rapat di manajemen tentang kurikulum; dan RPS sudah sesuai dengan program pembelajaran bahasa Arab di Program Studi Usaha Perjalanan Wisata.

Berdasarkan tabel 5, dosen memaparkan bahwa RPS dibuat sesuai kurikulum; RPS disampaikan kepada mahasiswa secara lisan, bukan tertulis. Mencakup pembelajaran yang akan dilakukan selama satu semester. 
Berdasarkan tabel 5, mahasiswa 1, mahasiswa 2, dan mahasiswa 5 mengemukakan bahwa dosen tidak menunjukkan RPS. Hal ini diperkuat dengan pemaparan mahasiswa 4 yang mengungkapkan bahwa dosen tidak menjelaskan RPS. Mahasiswa 4 mengira bahwa bahasa Arab tersebut tentang perkenalan Bahasa Arab dan tulisan Arab dari dasar. Senada dengan hal terseebut, mahasiswa 8 mengemukakan bahwa dosen tidak menjelaskan RPS. Mahasiswa 8 menduga bahwa bahasa Arab tersebut tentang perkenalan, bilangan, dan percakapan Bahasa Arab. Mahasiswa 7 turut menyepakati dengan mengatakan dosen tidak menunjukkan RPS, hanya menjelaskan apa saja yang akan dipelajari. Empat mahasiswa dengan tegas mengatakan bahwa dosen menjelaskan RPS. Mahasiswa 3 mengatakan bahwa dosen menjelaskan RPS. Mahasiswa 6 mengemukakan bahwa dosen menjelaskan RPS. Penjelasan tersebut sangat membantu dalam pembelajaran bahasa Arab. Mahasiswa 9 memaparkan bahwa dosen menjelaskan RPS. Menurut Mahasiswa 9, hal tersebut sudah memenuhi kebutuhan berbahasa Arab. Mahasiswa 10 menjelaskan bahwa dosen menjelaskan RPS. Mahasiswa 10 sangat terbantu bila kelak membuka usaha travel haji dan umrah. Berdasarkan hal tersebut dapat diketahui bahwa sebagian mahasiswa memaparkan bahwa dosen menjelaskan RPS, sedangkan sebagaian lainnya memaparka bahwa dosen tidak menunjukan RPS. Setelah dilakukan observasi, dapat diketahui bahwa kesenjangn yang terjadi disebabkan dosen yang tidak membagikan RPS secara tertulis, namun sebetulnya dosen memaparkan secara lisan. Menurut Majid, pentingnya RPS muncul karena perlu adanya serangkaian proses untuk menyusun bahan ajar, media, metode, pendekatan, dan penilaian dalam durasi waktu tertentu untuk mencapai suatu target. ${ }^{27}$

Berdasarkan Tabel 5, ada dua pihak pemangku kebijakan yang memahami tentang kurikulum, yaitu penanggung jawab bidang akademik dan ketua program studi. Penanggung jawab bidang akademik memaparkan bahwa sks kurang mencukupi, harus banyak praktik. Secara jujur, penanggung jawab bidang akademik menyadari bahwa sks yang tersedia untuk pembelajaran bahasa Arab memang belum terlalu cukup. Sedangkan beliau juga menyadari bahwa Bahasa Arab untuk tujuan khusus Pariwisata membutuhkan banyak praktek agar peserta didik menjadi terampil untuk berbahasa. Dengan jumlah sks yang terbatas, mata kuliah bahasa Arab untuk tujuan pariwisata jadi cenderung menampakan kesenjangan antara realitas kehidupan dengan prinsip-prinsip yang diajarkan. Latar belakang siswa yang mayoritas belum pernah belajar bahasa Arab sebelumnya, pada akhirnya membuat dosen tidak hanya menekankan pada praktik berbicara bahasa Arab, namun juga teori-teori kebahasaaraban. Karena untuk dapat berbicara bahasa Arab setidaknya mahasiswa harus mengetahui teori dasar bahasa Arab. Pada akhirnya waktu yang dibutuhkan untuk praktik berbicara bahasa Arab berkurang, karena mahasiswa juga harus mempelajari teori-teori kebahasaaraban. Hal tersebut sedikit disinggung oleh Mujib bahwa kontekstulaisme pembelajaran bahasa Arab kurang mementingkan esensi fungsi, yang pada akhirnya mengakibatkan peserta

27 Abdul Majid. Perencanaan Pembelajaran: Mengembangkan Standar Kompetensi Guru, (Bandung: Remaja Rosdakarya, 2011),17. 
didik mengalami kebingungan dalam menerapkan apa yang diketahui ke dalam aksi. ${ }^{28}$ Oleh karena itu, penanggung jawab bidang akademik mengharapkan agar bahasa Arab seyogyanya lebih memperbanyak praktek.

Berdasarkan Tabel 5, penanggung jawab bidang akademik memaparkan bahwa RPS yang dibuat oleh dosen mata kuliah bahasa Arab telah sesuai dengan kurikulum. Kesesuaian antara kurikulum dengan RPS amatlah penting, karena keduanya memiliki keterikatan satu sama lain. Sebagaiamana diungkapkan oleh Bahri bahwa kurikulum merupakan seperangkat rencana pembelajaran yang terdiri dari isi dan materi-materi pelajaran yang terstruktur, terprogram, dan terencana dengan baik. ${ }^{29}$ Maka RPS yang baik dan sesuai dengan kurikulum membantu proses berlangungnya kegiatan belajar mengajar di kelas menjadi lebih efektif dan efisien.

Merujuk pada Tabel 5, penanggung jawab bidang akademik juga mengungkapkan bahwa RPS telah sesuai dengan program pembelajaran bahasa Arab. Penyusunan RPS memang sangat penting agar pelaksanaan program pembelajaran bahasa Arab dapat tercapai sesuai target. Hal ini didukung pendapat Thomas bahwa seorang pendidik diwajibkan membuat Program Tahunan (Prota), Program Semester (Promes), Silabus dan RPP yang dibuat pada awal tahun dan awal semester dengan mengacu pada Standar Kompetensi dan Kompetensi Dasar (SKKD). ${ }^{30}$

Masih memaparkan tabel 5, penanggung jawab bidang akademik menekankan penguasaan kompetensi bahasa Arab. Penguasaan kompetensi bahasa Arab yang dimaksud adalah empat keterampilan berbahasa. Adapun tujuan pembelajaran bahasa Arab secara umum adalah agar peserta didik dapat menguasai empat keterampilan bahasa, yakni: menyimak, berbicara, membaca, dan menulis. ${ }^{31}$

Pada tabel 5, tampak harapan dari bagian akademik agar dalam rentang waktu 2 sks dalam satu semester, mahasiswa fasih dalam bahasa Arab. Hal ini nampaknya agak sulit untuk diwujudkan, mengingat kemampuan peserta didik yang beragam, dan mayoritas mahasiswa masih dalam tahap pemula. Hal tersebut sebagaimana yang diungkapkan oleh Garancang bahwa tidak semua mahasiswa memiliki kemampuan untuk memahami bahasa Arab secara mendalam. Salah satu faktornya adalah perbedaan latar belakang pendidikan mahasiswanya. Ada dua faktor yang menjadi penyebab timbulnya permasalahan dalam pembelajaran bahasa Arab di perguruan tinggi. Yaitu faktor internal (minat, motivasi, dan latar belakang) dan faktor eksternal (persepsi tentang bahasa Arab, kurikulum bahasa Arab, dosen bahasa Arab, metode pembelajaran bahasa Arab, dan media pembelajaran bahasa Arab). ${ }^{32}$ Oleh karena itu,

${ }^{28}$ Fathul Mujib. Rekonstruksi pendidikan babasa Arab: dari pendekatan konvensional ke intrgratif bumanis. (Yogyakarta: Pedagogia, 2010), 74.

29 Syamsul Bahri. "Pengembangan kurikulum dasar dan tujuannya". Jurnal Ilmiah ISLAM FUTURA. Vol XI, No.1, 2011, 19.

${ }^{30}$ Partono Thomas. "Manajemen Pembelajaran di SMK Negeri 2 Semarang". Jurnal Pendidikan Ekonomi Dinamika Pendidikan. 2011, 20.

${ }^{31}$ Sapri. "Metode pembelajaran bahasa Arab: antara tradisonal dan modern". INS ANLA Jurnal pemikiran alternatif pendidikan. Vol. 13, No. 3, 2008, hlm, 1.

32 S. Garancang. "Problematika pengajaran bahasa Arab pada perguruan tinggi islam". Jurnal Sosio-Religia. Vol. 9, No. 3, 2010, hlm, 960. 
untuk mewujudkan peserta didik yang fasih berbahasa Arab dalam 2 sks dalam satu semester rupaya memiliki tantangan yang cukup berat.

Berdasarkan tabel 5, prodi memiliki patokan RPS yang sesuai kurikulum, sedangkan materi diserahkan pembuatannya pada dosen. Tekait pembuatan materi, dosen membuatnya sesuai dengan tujuan pendidikan. Seperti yang dipaparkan oleh Bloom dalam Suwarno bahwa tujuan pendidikan dikelompokan menjadi tiga, yakni: cognitive domain, affective domain, dan psychomotor domain. Maka pembuatan materi yang dibuat oleh dosen disesuaikan dengan tujuan pendidikan, dan dipandu oleh prodi agar RPS sesuai kurikulum. ${ }^{33}$

Pada tabel 5, ketua prodi mengungkapkan bahwa RPS belum sesuai kebutuhan peserta didik. Bahwa peserta didik sebetulnya perlu mempersiapkan diri untuk tujuan yang lebih spesifik lagi yakni bahasa Arab untuk tujuan pariwisata. Sedangkan yang diajarkan pada peserta didik masih diawali sesuatu yang umum. Namun sesungguhnya, hal tersebut juga menjadi sesuatu yang cukup rumit karena peserta didik masih termasuk pembelajar pemula dalam mata kuliah Bahasa Arab. Diungkapkan oleh Khasairi bahwa pembelajaran bahasa Arab seringkali menghadapi berbagai kendala yang mengakibatkan hasil belajar yang dicapai tidak maksimal. Kendala tersebut terkadang berasal dari faktor guru yang kurang professional, kemampuan awal siswa yang rendah, media pembelajaran yang kurang tepat, materi pelajaran yang kurang memadai, lingkungan yang kurang mendukung, serta evaluasi yang tidak tepat sasaran. ${ }^{34}$

\section{Manajemen Akademik}

Berikut ini adalah data hasil wawancara yang mengupas fenomena tentang manajemen akademik untuk mata kuliah Bahasa Arab di Program Studi Usaha Perjalanan Wisata STIE Pariwisata YAPARI. Penjelasan-penjelasan temuan tersebut dipaparkan di bawah ini.

Tabel 6. Manajemen Akademik

\begin{tabular}{lllll}
\hline No. & Pertanyaan & Partisipan & Jawaban & \\
\hline 1 & Apakah terdapat pedoman & Penanggung & Belum ada pedoman wajib \\
wajib dalam pembuatan & jawab Bidang & pembuatan RPS & \\
& RPS? & $\begin{array}{l}\text { Apakah jumlah sks sudah } \\
\text { cukup? }\end{array}$ & & $\begin{array}{l}\text { Jumlah sks harus lebih banyak } \\
\text { praktek pengucapan dan berbicara, } \\
\text { sebaiknya ditambah sks nya. }\end{array}$ \\
\hline 3 & $\begin{array}{l}\text { Apakah RPS disusun sesuai } \\
\text { dengan kurikulum? }\end{array}$ & Dosen & RPS Sesuai kurikulum \\
\hline
\end{tabular}

Berdasarkan tabel 6 , ada dua partisipan yang memberikan pemaparan terkait manajemen akademik. Kedua partisipan tersebut adalah penanggung jawab bidang akademik dan dosen. Penanggung jawab bidang akademik memaparkan dua poin

33 W.Suwarno. Dasar-dasar ilmu pendidikan. (Jogjakarta: Ar-Ruzz Media,2008),35-36.

34 M.Khasairi. "Pengembangan komponen pembelajaran bahasa Arab di Madrasah Aliyah". Jurnal bahasa dan seni. 2013, 61. 
penting yakni: Belum ada pedoman wajib pembuatan RPS. Jumlah sks harus lebih banyak praktik pengucapan dan berbicara, sebaiknya ditambah sks nya. Penanggung jawab bidang akademik menyadari kekurangan akan ketidaktersediaan RPS. Padahal menurut Nadzir perencanaan memiliki peranan yang amat penting bagi seorang pendidik, khususnya ketika ia menjalankan tugasnya. Suatu kegiatan pembelajaran akan menjadi lebih optimal manakala seorang pendidik terlebih dahulu menyiapkan perencanaan pembelajaran. Perencanaan pembelajaran menjadi amat penting untuk dilakukan agar komponen-komponen pembelajaran dapat terorganisir dengan baik. ${ }^{35}$ Sedangkan dosen memaparkan bahwa RPS sesuai kurikulum. Sebagaimana telah dipaparkan Bahri bahwa secara umum kurikulum merupakan penjabaran dari visi, misi, serta tujuan pendidikan suatu bangsa. ${ }^{36}$ Oleh karena itu, adanya RPS ini dapat membantu agar pelaksanaan pembelajaran dapat mencapai tujuan pendidikan.

\section{Simpulan}

Berdasarkan uraian di atas, dapat disimpulkan bahwa secara umum perencanaan pembelajaran bahasa Arab di STIE Pariwisata sudah baik. Adapun fenomena yang dikupas dalam perencanaan terkait dengan Visi Misi Lembaga, Kurikulum, Rencana Pembelajaran Semester (RPS), dan Manajemen Akademik. Keseluruhan perencanaan sudah relevan satu sama lain. Semua elemen pemangku kebijakan seperti penanggung jawab bidang akademik, ketua Prodi, dan dosen saling bekerjasama untuk melaksanakan cita-cita bersama yaitu mewujudkan kampus yang lulusannya bisa melayani wisatawan mancanegara. Keinginan-keinginan mahasiswa pun cukup selaras dengan tujuan kampus dalam kecakapan berbicara bahasa Arab dalam ranah wisata. Hanya kendala yang muncul berasal dari manajemen akademik. Dimana belum ada arahan atau pedoman wajib secara tertulis terkait pembuatan RPS. Sehingga dosen masih membuatnya sesuai dengan arahan lisan dari para pemangku kebijakan. Solusi yang ditawarkan adalah dengan pemberian pedoman wajib pembuatan RPS secara tertulis, sehingga dosen bisa semakin menyelasarkan dengan visi misi dan kurikulum. Masih dalam penanggung jawab bidang akademik, kendala terjadi karena jumlah sks hanya ada 2 dalam satu semester. Solusi yang ditawarkan adalah ditambahnya jumlah 2 sks lagi pada semester lain, dimana pada semester tersebut lebih banyak praktek pengucapan dan berbicara.[

\section{DAFTAR RUJUKAN}

Bahri, S. "Pengembangan Kurikulum Dasar dan Tujuannya", Jurnal Ilmiah Islam Futura, Vol. XI, No.1, 2011.

Bulkisah. "Pembelajaran Bahasa Arab pada Perguruan Tinggi Agama Islam di Indonesia”, Jurnal Ilmiah DID AKTIKA, Vol. XII. No. 2, 2012.

35 M.Nadzir. "Perencanaan pembelajaran berbasis karakter". Jurnal Pendidikan Agama Islam. Vol. 02, No. 02, 2013, 339.

36 Syamsul Bahri. "Pengembangan kurikulum dasar dan tujuannya". Jurnal Ilmiah ISLAM FUTURA. Vol XI, No.1, 2011. 
Arabiyât Jurnal Pendidikan Bahasa Arab dan Kebahasaaraban, 5 (1), 2018

Garancang, S. "Problematika Pengajaran Bahasa Arab pada Perguruan Tinggi Islam", Jurnal Sosio-Religia, Vol. 9, No. 3, 2010.

Hamalik, O. Proses Belajar Mengajar. Jakarta: PT. Bumi Aksara, 2010.

Hartono. "Pendidik dan Peserta Didik dalam Perspektif Filsafat Pendidikan Islam", Jurnal Potensial, vol. 13, 2014.

Herayanti, L, et al. "Pengembangan Media Pembelajaran Berbasis Moodle pada Matakuliah Fisika Dasar", Jurnal Cakrawala Pendidikan, Th. XXXVI, No. 2, 2017.

Hutasoit, A.B.R \& Sari, R.L. "Analisis Permintaan Wisatawan Mancanegara Berwisata di Tuktuk Siadong, Kabupaten Samosir" Jurnal Ekonomi dan Kenangan. Vol. 2, No. 10, 2014.

Khasairi, M. "Pengembangan Komponen Pembelajaran Bahasa Arab di Madrasah Aliyah", Jurnal Bahasa dan Seni, Nomor 1, 2013.

Kurt A. Stahura, et al. "Emergency Planning and Recovery for Terror Situations: An Analysis With Special Reference to Tourism", Jurnal Worldwide Hospitality and Tourism Themes, Vol. 4 Iss: 1, 2012.

Majid, A. Perencanaan Pembelajaran: Mengembangkan Standar Kompetensi Guru. Bandung: Remaja Rosdakarya, 2011.

Mujib, F. Rekonstruksi Pendidikan Bahasa Arab: dari Pendekatan Konvensional ke Intragratif Humanis. Yogyakarta: Pedagogia, 2010.

Mulyasana, D. Pendidikan Bermutu dan Berdaya Saing. Bandung: Remaja Rosdakarya Offset, 2012.

Nadzir, M. "Perencanaan Pembelajaran Berbasis Karakter", Jurnal Pendidikan Agama Islam. Vol. 02, No. 02, 2013.

Pribadi, A.B. Model Desain Sistem Pembelajaran. Jakarta: Dian Rakyat, 2010.

Ramli, M. "Hakikat Pendidik dan Peserta Didik", Jurnal Tarbiyah Islamiyah, Vol. 5, No. $1,2015$.

Rochgiyanti. "Pembelajaran Paket B di PKBM Barito Kota Banjarmasin". Jurnal Pendidikan Progresif, Vol. 3, No. 2, 2013.

Sapri. "Metode Pembelajaran Bahasa Arab: Antara Tradisonal dan Modern", INS ANLA Jurnal Pemikiran Alternatif Pendidikan, Vol. 13, No. 3, 2008.

Sauri, S., et al. Filsafat Ilmu Pendidikan Agama. Bandung: Arfino Raya, 2010.

Sugiyono. Metode Penelitian Pendidikan Pendekatan Kuantitatif, Kualitatif, dan R\&D. Bandung: Alfabeta, 2013.

Supriadie, D. dan Darmawan, D. Komunikasi Pembelajaran. Bandung: Remaja Rosdakarya, 2012.

Suwarno, W. Dasar-Dasar Ilmu Pendidikan. Jogjakarta: Ar-Ruzz Media, 2008.

Thomas, P. "Manajemen Pembelajaran di SMK Negeri 2 Semarang”. Jurnal Pendidikan Ekonomi Dinamika Pendidikan. Vol. VI, No. 1, 2011.

Undang-Undang No. 20 Tahun 2003 tentang Sistem Pendidikan Nasional. 